\title{
МАРКО КАТИТ
}

\section{ЈЕДНА НЕОБИЧНА СЦЕНА НА ХАҢИЈСКОЈ ИКОНИ ИЗ ЦРКВЕ РУЖИЦЕ}

\begin{abstract}
САЖЕТАК:
У раду се проучава једна од представа на иконографски сложеној јерусалимској икони из 1819. године, сачуваној у Цркви Ружици на Калемегдану. На овој представи централна је икона Богородице с Христом, коју Св. ап. Лука представља Богородици. На основу поређења с касније насталим графикама аутор долази до закључка да је реч о представи предања о чудотворној икони из манастира Кико на Кипру. Поменуту икону је насликао Св. ап. Лука, а својим речима ју је Богородица благословила. Ово предање је играло улогу у оправдању култа икона, али и у учвршћивању престижа саме кикоске иконе. На основу времена настанка јерусалимске иконе, као и појединих бугарских икона идентичне садржине, јасно је да су графике које су настале касније имале ранију варијанту, чије изворно полазиште може бити једна од икона на иконостасу цркве кикоског манастира. Ова ранија варијанта била је позната у иконописачким радионицама на Балкану и у Палестини у првој половини XIX века.
\end{abstract}

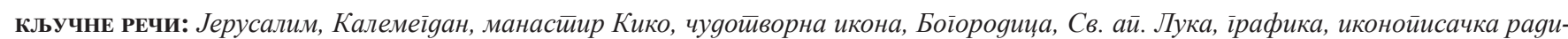
онииа, Балкан, Палестинна

ABSTRACT:

The paper reviews the scene on the Jerusalem proskynetarion Icon - an iconographically complex pilgrimage icon dating from 1819 and kept in the Rose Church at the Belgrade Fortress. The central part of this scene depicts St Luke Presenting the Icon of the Theotokos to the Virgin Mary. By comparison with more recent graphics, the author concludes that this tradition was related to the miraculous icon from the Kykkos Monastery on Cyprus, which is believed to have been painted by Apostle Luke himself and blessed by the words of the Holy Mother. This legend played its role in justifying the cult of icons in general, but also in strengthening the prestige of the Kykkos Icon itself. Judging by the dates of the Jerusalem proskynetarion from the Ružica (= the Rose) Church and ceratin Bulgarian icons of the same type, it may be concluded that the latter ones had an earlier variant, a model of which could have been one of the icons from the Kykkos Monastery; it is likely that the Balkan and Palestinian workshops of the first half of the $19^{\text {th }}$ century were aware of this earlier variant.

KEYwORDS: Jerusalem, Belgrade Fortress, Kykkos Monastery, miraculous icon, Mother of Jesus, Apostle Luke, graphic, iconographers' workshop, Balkans, Palestine

$\mathrm{Y}$

радионици за конзервацију и рестаурацију Републичког завода за заштиту споменика културе у Београду током 2004-2005. године на захвату се нашла репрезентативна хаџијска икона Јерусалим ${ }^{1}$ (сл. 1). Она је, са извесним бројем других икона из XVIII и XIX века, пронађена у звонику Цркве Ружице на Калемегдану 2002-2003. године. После завршених радова, Јерусалим је враћен у цркву ${ }^{2}$. Јерусалими су представе библијске сакралне топографије у Светој земљи - Палестини, настајали у тамошњим зографским радионицама, одакле су их хаџије доносиле са собом с поклоничког путовања. ${ }^{3}$ По натпису у декоративној картуши на полеђини, икону је с хаџилука у Палестину 1819 . донео извесни Хаџи Петар (сл. 2), али откад тачно се она налази у цркви - није познато. Икона се одликује особеним и живописним стилом, карактеристичним за групу Јерусалима из последње деценије XVIII и прве две, три деценије XIX века. Реч је о иконама на којима се у великој мери користи упадљива јарконаранџаста боја, првенствено за оквире сцена и појединачних представа, контрастирана с небескоплавом бојом на њиховој позадини. Натписи и орнаменти су по правилу златни, те тако премошћују овај јак контраст. Гама осталих боја је сасвим ограничена: црна, бела, зелена, смеђа, беж, окер, тамноплава и жута. Наглашен је линеарни елемент, а представљене фигуре и архитектура одликују се извесном непропорционалношћу. Од изузетне важности је да су натписи на овој икони словенски. На Јерусалимима 


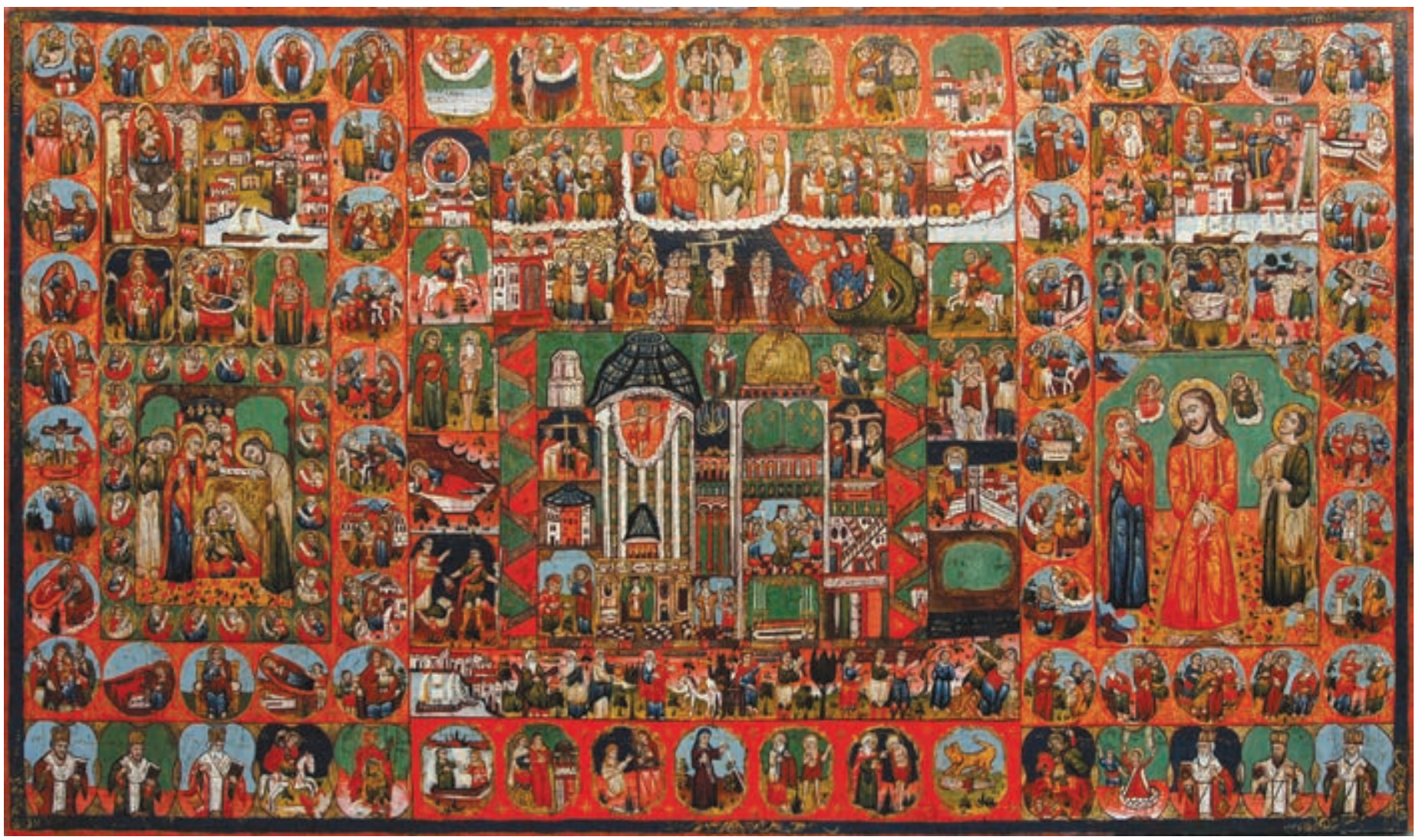

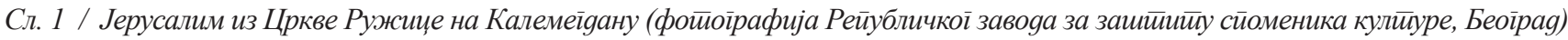

из XVIII и прве половине XIX века изразита је доминација грчких натписа, док су словенски реткост. Тек на иконама насталим након 1850. словенске натписе налазимо у једнакој мери као и грчке.

Поред уочљивог стила, ова икона се одликује и изразитом иконографском разуђеношћу. Јасно је да моделе за велики део представа треба тражити у ранијем иконопису и графици. ${ }^{4}$ Посебно упадљива на овом Јерусалиму, као и на свим другим иконама ове групе из касног XVIII и раног XIX века, јесте пред-

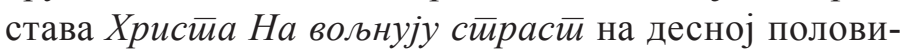
ни иконе, окруженог сценама Христових страдања и чуда ${ }^{5}$. Ипак, овде желимо скренути пажњу и поближе проучити аналогну представу на левој страни иконе (сл. 3), у пољу окруженом сценама Акатиста.

Централна на овој композицији с више фигура јесте икона Богородице с Христом. Њена позадина је златна. Богородица, означена црвеним словима $M P \Theta O Y$ око главе, представљена је до испод појаса, држи малог Христа на својој левој руци, док десном придржава његову десну руку. Фигуре су оријентисане ка левој страни слике. Богородица је одевена у плаву хаљину и црвени мафорион са златним наборима. Преко мафориона има још једну дугачку мараму на глави. Марама је светлобеж боје с распознатљивим цветним орнаментима и широким златним обрубом. На глави Богородице је круна. Мали Христос је у зеленој туници са златним наборима, која му сеже до глежњева. У десној руци, оној коју му придржава Богородица, држи развијен свитак без натписа окренут нагоре, а левом додирује Богородичину горњу беж мараму. Богородица главу лагано сагиње према Христовој; обоје имају поглед испуњен нежношћу. Ову икону Богородице с Христом са десне стране композиције придржава Свети апостол Лука, у зеленој туници и дугачком беж огртачу. Представљен је дубоко погнуте главе у знак поштовања према Богомајци, која стоји насупрот њега, лево од иконе између њих. Она десну руку држи подигнуту, а левом придржава развијени свитак без натписа који се налази тик изнад иконе. Одевена је у плаву хаљину и црвени мафорион са златним наборима. Леви рукав мафориона виси преко иконе. У позадини, између Св. ап. Луке и Богородице представљене су три свете жене, док иза Богородице стоји Св. ап. Јован. И он држи дубоко погнуту главу, а одевен је у беж тунику и зелени огртач са златним наборима. Богородица и два апостола су представљени са златним ореолима око главе. Лица и тканине на описаним фигурама су пажљиво изведени техником подсли- 


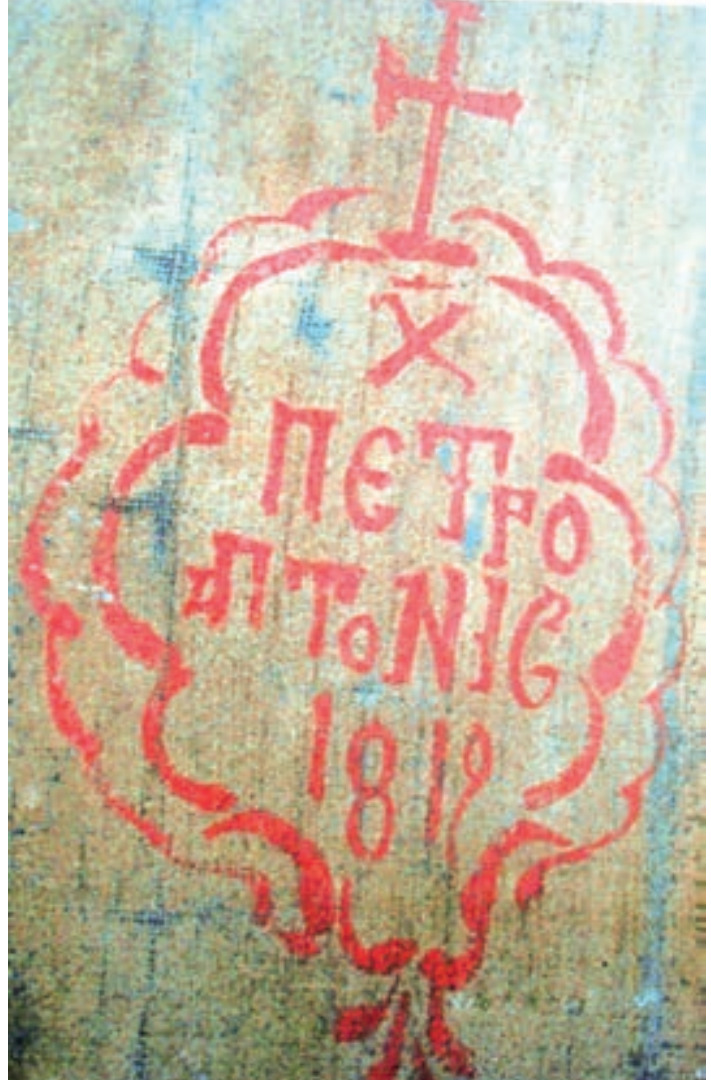

Сл. 2 / Наййис Хаии Пейра из 1819. іооине у карииуши, йолеЂина иконе (фотиоїрафија Рейубликоі завоgа за зашйийу сйоменика кулииуре, Беоїраg)

кавања у основној боји, преко које је у одговарајућој боји изведено сенчење пажљивим потезима киста. Оквир сцене је архитектура, у виду три лучна полукружна отвора на стубовима. Средњи отвор је тамноплаве боје и у његовом оквиру су представљена четири кандила. Два бочна отвора су зелене боје. Најнижи део представе, који изображава под на којем стоје поменуте личности, златне је боје и представљен је посут ситним црвеним цветовима налик на макове. Ова композиција није идентификована никаквим натписима. Окружена је минијатурним представама 24 пророка у медаљонима. Ови медаљони имају златну позадину, на зеленој правоуганој траци. Пророци гледају у правцу композиције, а представљени су попрсно и с развијеним свицима без натписа у рукама. Овакву композицију налазимо на још свега два публикована Јерусалима. Први је из 1815. године и чува се у Градској уметничкој галерији у Пловдиву (Бугарска). ${ }^{6}$ Други је у цркви манастира Св. Текле у Малули (Сирија), такође по свој прилици из друге деценије XIX века. ${ }^{7}$ Ова два примерка се од београдског разликују у појединим секундарним детаљима, али је срж сцене иста.

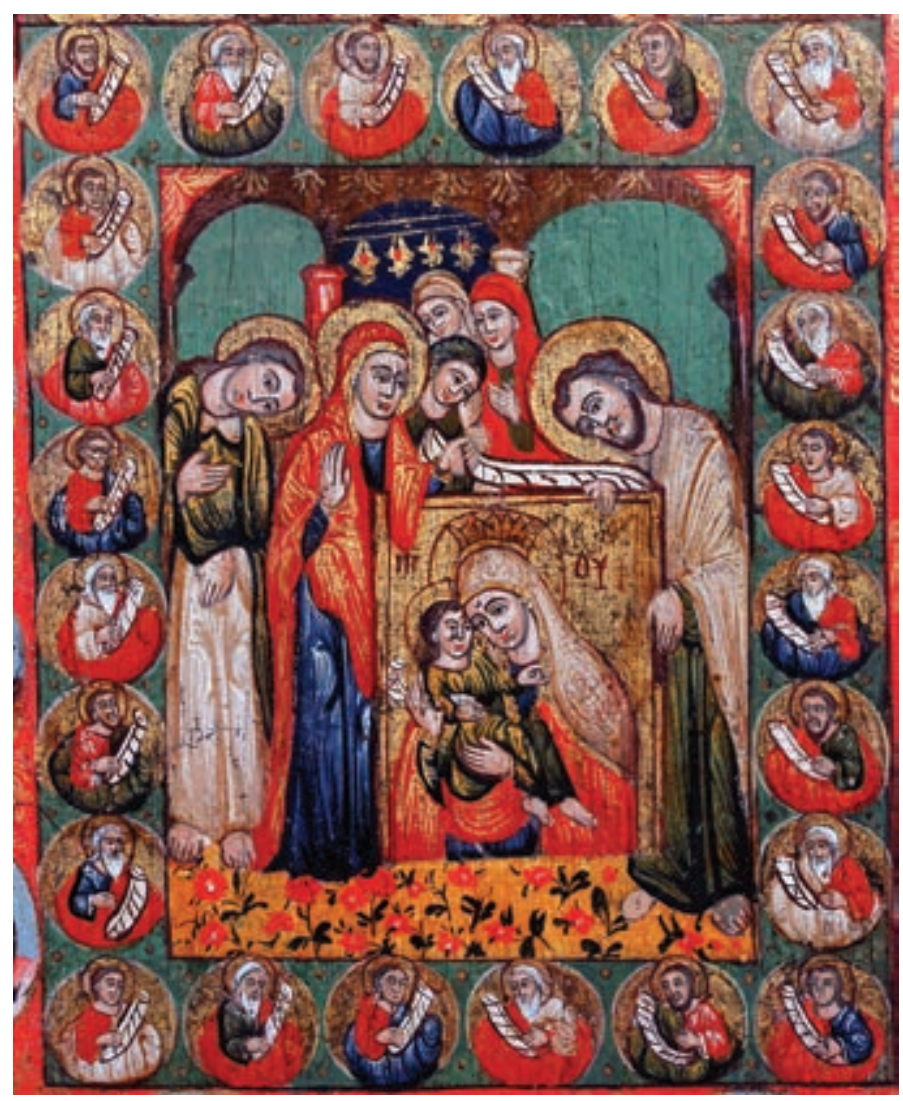

Сл. 3 / Светии айостиол Лука йредсйавља Боїородици икону коју је насликао, дет̄аљ Јерусалима (фот̄оїрафија Рейубликої завоgа за заиииийу сиоменика кулииуре, Беоїраg)

Тумачење сижеа и порекла ове композиције је на први поглед једноставно, али, са друге стране, показује одређене сложености. Реч је о сцени Св. Лука йреgстиавља Боїородици икону коју је насликао. У вези с њом треба истаћи две чињенице. Прва је да је ова сложена композиција позната из графика, на које ћемо се вратити касније, али знатно каснијег времена настанка од друге деценије XIX века. ${ }^{8}$ Друга чињеница је да је икона коју Св. Лука представља Богородици позната чудотворица из манастира Кико на Кипру - Богородица Кикотиса, или како се обично назива Елеуса $\bar{u} y$ Кику ( $H^{\prime} E \lambda \varepsilon o v ́ \sigma \alpha$ tov Kíкоv). Ова икона је главна и најчувенија православна светиња на острву Кипру, где је, како се сматра, од XII века. Осведочила се многобројним чудима и преживела неколико великих несрећа које су задесиле манастир. ${ }^{9}$ Налази се на посебном проскинитариону у оквиру иконостаса манастирске цркве, окована је сребром и покривена тешким везеним покровом, који се никад не скида (или се то чини врло ретко), тако да саму икону нико није видео, чак ни чланови манастирског братства. ${ }^{10}$ Ширење популарности Богородице Кикотисе ван Кипра дешава се већ током 


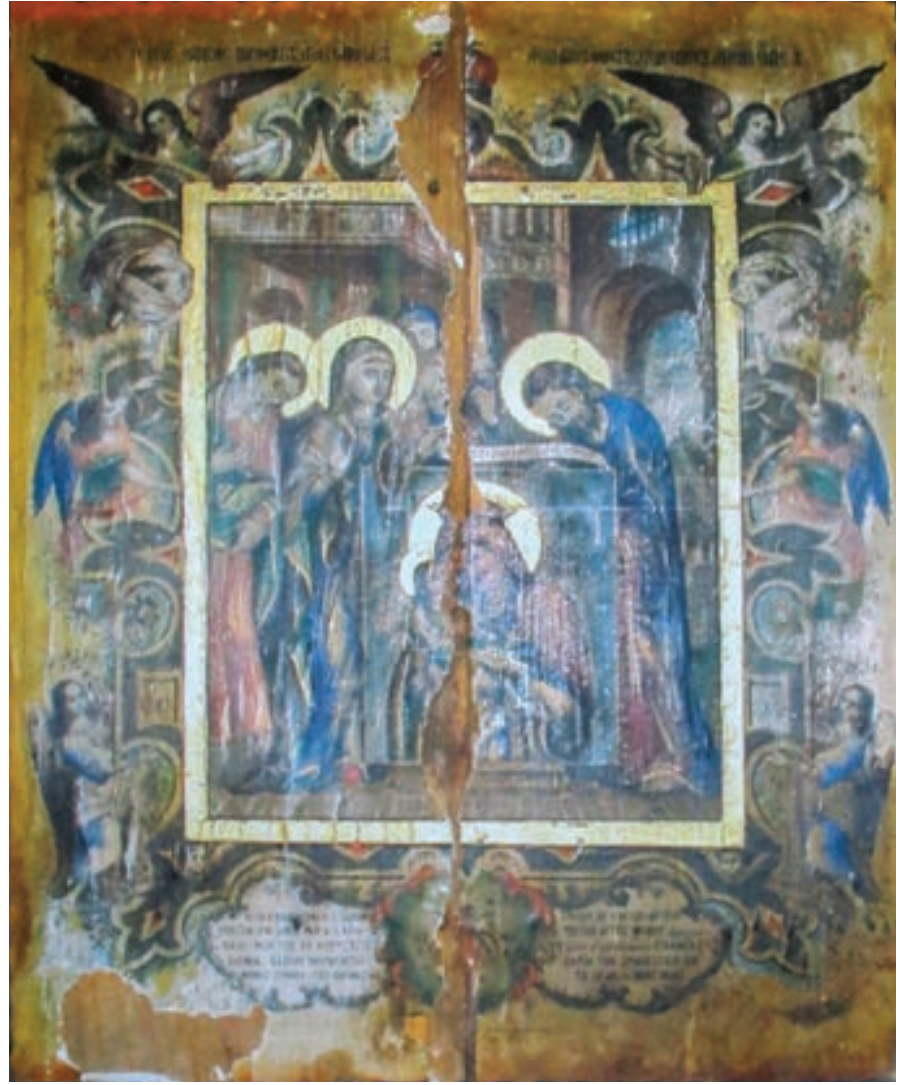

Сл. 4 / Светии айосӣол Лука йреgстиавља Боїородици икону коју

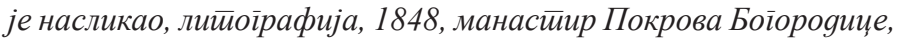
Самоков, Буїарска (извор: Джурова 2002, без нумераџије)

XVII века, а посебно у периоду друге половине XVIII и почетка XIX века. Тада настаје низ реплика ове иконе широм источног Медитерана, а манастир Кико издаје посебну брошуру о икони ${ }^{11}$, као и више графика с њеним представама. ${ }^{12}$ У том периоду ова икона се реплицира и на Јерусалимима, али углавном једноставније него овде. ${ }^{13} \mathrm{C}$ обзиром на то да је посреди чудотворна икона, овде је важно напоменути: опште место разлога за реплицирање чудотворних икона лежи у веровању да се део моћи тауматургијског прототипа преноси на копију; она тиме постаје ефикасно средство маријанске заштите. ${ }^{14}$ То ће свакако и овде бити случај. Представа је окружена пророцима и са 24 сцене Акатиста, чиме је изведена њена асоцијација с темом Пророци су иее наїовесииили, али и скренута пажња да угледну чудотворицу ваља прослављати служећи Акатист пред њом. Може бити да је конкретан разлог био у томе што је Субота Акатиста у Посном триоду, између осталог, посвећена и прослављању чудотворних икона. Тиме би кикоска чудотворица била свесно постављена за икону која се прославља на овај начин, и то управо у време кад се хаџије налазе у Јерусалиму. ${ }^{15}$

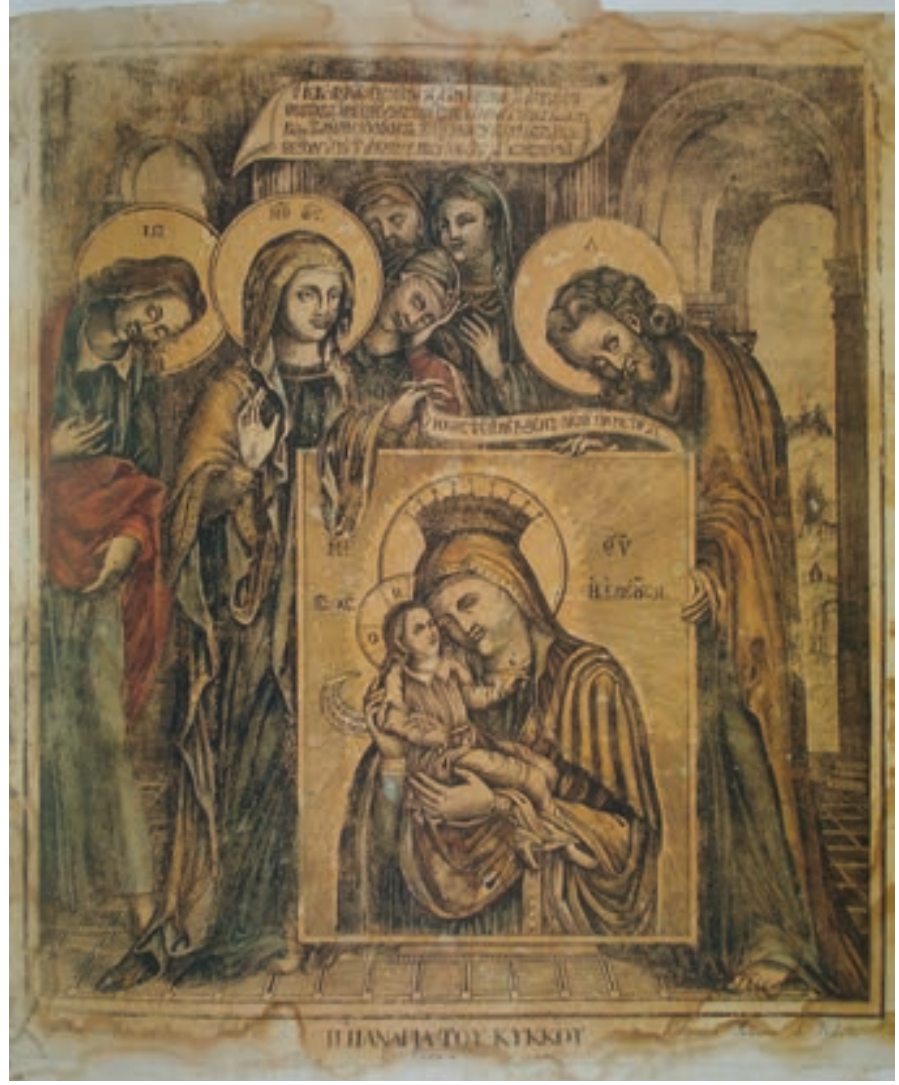

Сл. 5 / Светии айостиол Лука йреgстиавља Боїородиии икону коју

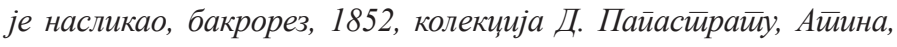
Грчка (извор: Papastratou 1990, 587)

Овде се враћамо на досад само укратко поменуте графике из каснијег времена, тачније средине XIX века. Прва је литографија настала у Константинопољу $1848 .{ }^{16}$ (сл. 4), а друга бакрорез настао у Атини 1852. године ${ }^{17}$ (сл. 5). Грчки натписи на њима појашњавају појединости композиције коју проучавамо. Натпис у врху даје тачан назив: Св. Лука йреgстиавља Пресвейој Боіородици свешиу икону коју је насликао. На свитку који

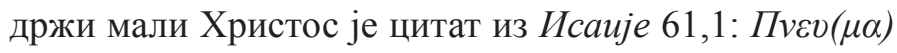
Kıрıоv... ${ }^{18}$, иначе уобичајена одлика иконографије ове чудотворице. Ипак, овде је најважнији натпис на развијеном свитку који држи Богородица на овим графи-

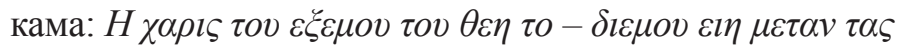
- Нека милости Оноїа койа сам роgила буgе на њој. ${ }^{19}$ То су речи које изговара Богородица кад јој Св. ап. Лука подноси икону. По старом предању, Богородица је изговорила ове речи кад јој је Св. ап. Лука поднео три иконе c њеним ликом које је насликао. ${ }^{20}$ Касније су ове речи благослова везиване искључиво за кикоску икону. ${ }^{21} \mathrm{He}$ само да је света икона један од аргумената одбране култа икона тиме што ју је насликао Св. ап. Лука него ју је и Богородица благословила својим речима. 
Представа са Јерусалима из Цркве Ружице из 1819. године ${ }^{22}$ непосредно доказује да су издања графика из 1848. и 1851. године имала раније верзије. Слично је и са извесним бројем икона са идентичном представом, насликаних у Бугарској током прве половине XIX века. Најважнију од њих Е. Попова ${ }^{23}$ приписује познатом зографу Јоану Поповичу из града Елене и датира је у двадесете године XIX века. Иста ауторка такође сматра да су учитељи овог зографа Јосиф и Дамаскин, који су 1818. дошли у Елену са Атоса да осликају Цркву Св. Николе, са собом донели графику са оваквом представом. Њу би касније Јоан Попович користио у свом раду. ${ }^{24}$ Слично бисмо могли сматрати кад је реч о хаџијским иконама које настају у палестинским зографским радионицама. Графика је на сличан начин, можда путем поклоника или клира, дошла до Свете земље. Очито су Јерусалими створени у другој деценији XIX века у палестинским иконописним радионицама, нешто касније настале иконе бугарских зографа, као и графике из средине XIX века сви рађени су на основу старијег примера који је био познат у сликарским и графичким радионицама на османском Балкану и у Палестини. Проблем је његова идентификација. Највероватније је, видели смо, реч о графици, али остаје питање првобитног узора. На иконостасу цркве самог манастира Кико налази се икона врло слична поменутим представама, која им је по свој прилици била узор. Јоанис Корнарос је 1792. године насликао две иконе за овај иконостас. Једна од њих се налази непосредно уз саму Богородицу Кикотису, и на њој је представљен Св. ай. Лука како слика икону Боїородице. Икона је натписом датирана у 1792. годину. Друга икона, на делу иконостаса који прелази на северни зид, носи представу Св. ай. Лука Боїородици йреgстиавља икону коју је насли$\kappa a o^{26}$ (сл. 6). Икона се одликује раскошним, китњастим стилом са доста рококо елемената, карактеристичним за Корнароса. Структура сцене је готово идентична оној коју овде проучавамо, али нема Св. ап. Јована нити светих жена у Богородичиној пратњи, него су представљена три анђела око Св. ап. Луке. ${ }^{27}$ Богородица својом левом руком и рукавом мафориона који је покрива непосредно додирује икону коју јој приноси Св. ап. Лука, а речи благослова које изговара представљене су у виду зрака који излази из њених уста. Ове речи су готово идентичне онима на свитку на графикама. Престижнији пример тешко да се може замислити. Сматрамо да је икона приписана Корнаросу са иконостаса цркве манастира Кико, близу саме чудотворице коју прославља, била узор за по свој прилици графику, засад непознату, која је са своје стране повратно деловала на иконопис. Послужила је као образац представама на Јерусалимима, иконама у

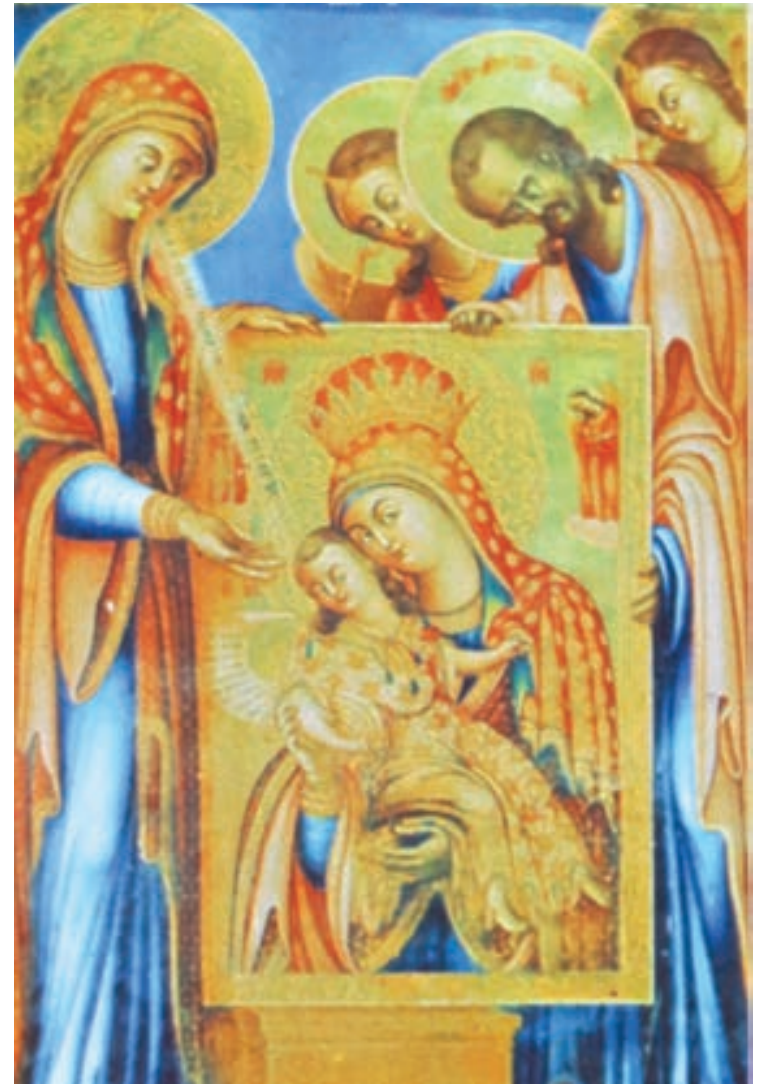

Сл. 6 / Светии айостиол Лука йреgсииавља Боїородици иконукоју је насликао, икона йрийисана Јоанису Корнаросу, 1792, иконоситас иркве манастира Кико, Кийар (извор: Chrysostomos 1969: 38)

Бугарској, као и каснијим грчким графикама из средине XIX века. ${ }^{28}$ Ипак, икона је на овим каснијим примерцима слободно интерпретирана. Речи које изговара Богородица су на свитку који она држи у руци, а не излазе у виду зрака из њених уста. Богородица икону не додирује руком, него само леви рукав мафориона делом прелази преко иконе. Додате су личности Св. ап. Јована и свете три жене, а у позадини је видљива архитектура. ${ }^{29}$ Било како било, тешко је замислити да икона са иконостаса цркве манастира Кико, готово непосредно уз саму икону Богородице Кикотисе, није била фундаментални узор под чијим утицајем је обликован један, макар и мањи део, православне визуелне културе на османском простору током неколико деценија XIX века. Отуда овакву представу видимо изображену и на Јерусалиму донесеном у Србију с поклоничког путовања у Свету земљу 1819. године, а данас у Цркви Ружици на Калемегдану.

Марко Ж. Катић,

историчар уметности М. А. докторанд

Београд

aspazije@gmail.com 


\section{НАПОМЕНЕ:}

1] О радовима на икони: Станковић 2006. Овде истичемо предусретљивост Браниславе Станковић, недавно преминуле конзерваторке Републичког завода у Београду, у уступању фотографских снимака и калка иконе, као и у техничким информацијама о њој.

2] Икона се данас налази у свештеничкој канцеларији уз параклис Свете Петке.

3] О јерусалимима в.: Макуљевић 2005; 2006; 2014; Катић 2012.

4] Пре свега мислимо на представе Богородице Живоносног источника, Синаја и Св. Горе. О графикама са овим представама Papastratou 1990: 172-182, 337-381, 385-402.

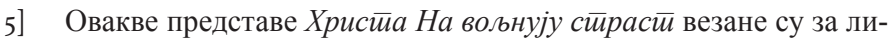
тургијско обележавање Страсне седмице.

6] Москова 2001: 23; Паскалева 2011: 454-455. Сцена на икони у Пловдиву је без фигура Св. ап. Јована и светих жена, а у самом дну је представљен Јесеј који лежи.

7] Kazakou and Skoulas 2007: 303-305. Судбина ове иконе, као и целокупног манастира у Малули, с обзиром на текући рат у Сирији, неизвесна је.

8] Papastratou 1990: 508, cat. no. 542; 509, cat. no. 543.

9] О историји манастира, иконе и њеног култног поштовања постоји огромна литература, од које овде наводимо само најосновнија дела: Chrysostomos 1969; Hackett 1972; Татић-Ђурић 2007, као и литературу у доњим фуснотама.

10] Илустрација иконе на проскинитару с тешким везеним покровом: Chrysostomos 1969: 28, 30-31.

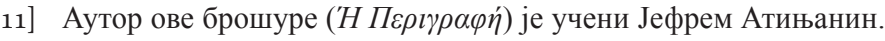
Постоји у издањима из $1751,1782,1817$. и 1819 . године. Постоји и савремено издање, с паралелним грчким оригиналним текстом и преводом на енглески језик: Ephraim 1996.

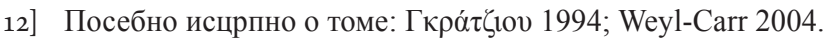

13] Фигура Богородице с Христом обично је окружена са 12 попрсних представа пророка у медаљонима, који формирају крошњу стабла што израста из фигуре лежећег Јесеја у дну. У композицију су укључене и руже, тако да овакве представе постају сложена иконографска симбиоза тема Богородице Кикотисе, Руже Неувеле, Пророци су Те наговестили и Јесејевог Стабла. Упадљив пример се сачувао на Јерусалиму у збирци Цркве Св. Спиридона у Трсту: Давидов 2007: 216-217, посебно 228, с видљивим натписом 'H тоv Kiкov.

14] Остаје нејасан конкретан разлог реплицирања Кикотисе на Јерусалимима, пошто ова икона не спада у палестинску сакралну топографију, будући да је на Кипру. По свој прилици разлог лежи у њеној популарности међу православнима у оновременој Палестини, али то остаје предмет за посебно истраживање.
15] Иначе се ова икона засебно прославља на дан Богородичиног Рођења.

16] Papastratou 1990: 508, cat. no. 542, по наруџби манастира Кико, с наведеним сачуваним примерима на грчким острвима Тиносу и Хидри. Још један оштећен примерак ове графике у боји сачуван је у манастиру Покров Богородице у Самокову: Джурова et al. 2002: без нумерације.

17] Papastratou 1990: 509, cat. no. 543, с наведеним сачуваним примерима на Тиносу, у Атини и Александрији.

18] Дух је Госйоgа Боїа на мени, јер ме Госйоg йомаза gа јављам gобре ілласе кройкима, йосла ме gа завијем рањене у сриу, gа оїласим заробљенима слобоgу и сужьима gа ће им се ойвори-

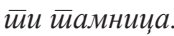

19] Грчки натпис цитиран по: Попова 1998: 38.

20] Предање је први пут поменуто у писму тројице источних патријарха иконокластичком цару Теофилу 836. године: Нав. дело: 32.

21] Нав. gело: 37-38. На овоме се посебно инсистира у другом издању Воgича из 1782. године, у предговору који је тексту Јефрема Атињанина написао Серафим Писидијски, Еvтvх1о 2001: 388-389.

22] Такође и представе са друга два поменута Јерусалима.

23] Попова 1998: 33

24] Нав. gело: 37-39, у Музеју у Елени. Друга икона је у Музеју у Великом Трнову, исти

25] Због њиховог блиског времена настанка наглашавамо да не треба искључити могућност да су сва три Јерусалима са овом представом рад једне исте иконописачке радионице.

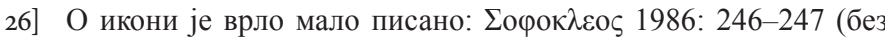
илустрације); једина репродукција у: Chrysostomos 1969: 38. Икона је по стилским одликама приписана Корнаросу. Њен положај на иконостасу не дозвољава сагледавање да ли на њој постоје година и потпис сликара.

27] Они су око њега и на икони где је представљен како слика икону Богородице.

28] Паралелни процеси у формирању православне визуелне културе у XVIII и XIX веку, у смислу међусобног утицаја графике и иконописа, могу се уочити и на другим примерима, и овај је свакако далеко од усамљеног.

29] Може се размишљати о евентуалном посреднику између иконе са иконостаса и графика због описане интерпретације. То би могла бити окована целивајућа икона испод престоне иконе Св. ай. Лука йредстиавља Боіоородици икону коју је насли$\kappa a о$, видљива на појединим фотографијама манастирског наоca, Chrysostomos 1969: 24. Ипак, она нигде није публикована нити јасно снимљена, тако да ово питање остаје нерешено. 


\section{ЛИТЕРАТУРА:}

Weyl-Carr, A. (2004), Reflections on the Life of an Icon: the Eleousa

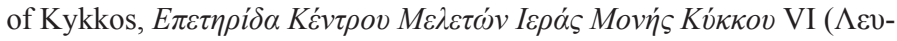

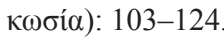

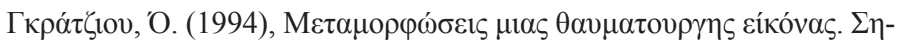

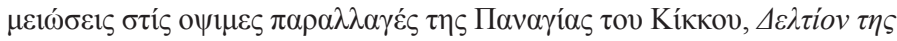

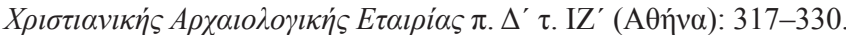

Давидов, Д. (2007), Срби и Јерусалим, Београд: Политика.

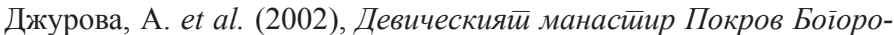
gици в Самоков, София: Центръ за славяно-византийски проучвания „Проф. Иван Дуйчев“ към СУ „Св. Климент Охридски“.

Ephraim, A. (1996), A Narrative of the Founding of the Holy Monastery of Kykkos and the History of the Miraculous Icon of the Mother of God, trans. Jakovljevic A., Nicosia: Kykko Monastery.

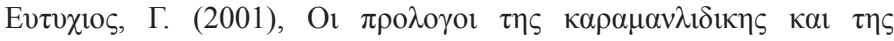

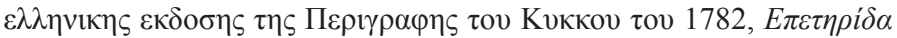

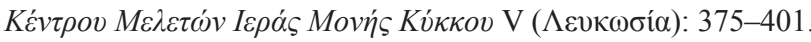

Kazakou M. and Skoulas V. (eds.) (2007), Egeria : Monuments of Faith in the Medieval Mediterranean, Athens: Hellenic Ministry of Culture and the Participants of Egeria Program.

Катић, М. (2012), Чейири Јерусалима - хаиијске иконе из иркве Усйенија Пресветие Боі̄ородиие у Ливну, Бањалука: Музеј Републике Српске.

Макуљевић, Н. (2005), Визуелна кулииура и ирривайни ияенииииеей иравославних хришћана у 18. веку, у: Приватни живот у српским земљама у освит модерног доба, ур. А. Фотић, Београд: Clio: 72-111.

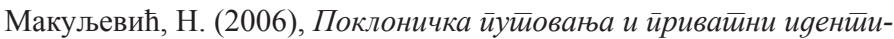
$\bar{u} e \bar{u}$, у: Приватни живот код Срба у XIX веку, ур. А. Столић и Н. Макуљевић, Београд: Clio: 807-837.
Makuljević, N. (2014), Pilgrimage and Memory: The Picture of the Holy Land in early modern visual culture of the Balkans, in Heilige Landschaft - Heilige Berge. Achter Internationaler Barocksommerkurs 2007. Stiftung Bibliothek Werner Oechslin, Einsiedeln. Einsiedeln: Edition Bibliothek Werner Oechslin - Zürich: Gta Verlag: 54-65.

Москова С. (2001), Пьтят на хаджията (структурна схема на една изложба), Проблеми на изкусиивотио III (София): 18-25.

Papastratos, D. (1990), Paper Icons. Greek Orthodox Religious Engravings 1665-1899, trans. Leatham J., Athens: Papastratos.

Паскалева, К. (2011), Ерусалимията - знак за поклонничество до

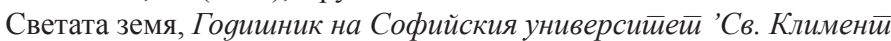
Охрияски'. ЦСВП 'Иван Дуйчев', XCVII (XVI) (София): 442-468.

Попова, Е. (1998), Реинтерпретации на чудотворната икона на св. Богородица от Кикос в българската живопис от края на 18-19 век, Проблеми на изкустивойо 4 (София): 32-41.

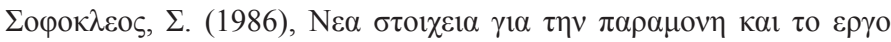

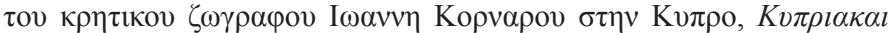
$\sigma \pi о v \delta \alpha l \mathrm{~N}(\Lambda \varepsilon v \kappa \omega \sigma i \alpha): 227-256$

Станковић, Б. (2006), Јерусалимска икона из цркве Ружице на Београдској тврђави, Гласник Друшишва конзервайора Србије XXX (Београд): 172-174.

Татић-Ђурић, М. (2007) Икона Боїородице Кикойисе, у: Студије о Богородици, Београд: Јасен: 429-444.

Hackett, B. D. J. (1972), A History of the Orthodox Church of Cyprus, New York: Burt Franklin.

Chrysostomos, Abbot (1969), The Holy, Royal Monastery of Kykko Founded with a Cross, trans. Phillips D. W. and Sofroniu S. A., Cyprus: Kykko Monastery.

\section{Summary: MARKO KATIĆ}

\section{AN UNUSUAL SCENE ON THE PROSKYNETARION ICON IN RUŽICA CHURCH}

In the iconographic composition of the Jerusalem proskynetarion, the Hajji's icon from 1819, preserved in Ružica Church in Kalemegdan, the prominent place is occupied by an unusual scene. It shows the central icon of the Holy Mother of God with Christ the Child that is handed by Luke the Evangelist who is also holding an open scroll, with no inscriptions on it. St. Apostle John and three holy women are also depicted. Based on its comparison with copperplate engravings that were created later in the time, originating from the mid- $19^{\text {th }}$ century, it can be undoubtedly concluded that this is the scene of Apostle Luke presenting to the Holy Mother the Icon he painted himself. This tradition is related to the miraculous Icon from the Kykkos Monastery of Cyprus. This icon is believed to be painted by Apostle Luke and blessed by the words of the Holy Mother. The copperplate engravings on the open scroll have the inscription of words by which the Holy Mother blessed the Icon. The legend had played its role in justifying the cult of icons in general, but also in further establishing the prestige of the particular Kykkos Icon. The exact reasons of presenting the Kykkos Icon on the Jerusalem proskynetarion presently remain unknown. Be it as it may, the miraculous icon is brought to the connection with the representations of the Prophets and the Akathistos Hymn, the clear 
signs of its high status. Based on the time of creation of Jerusalem in Kalemegdan, as well as individual Bulgarian Icons depicting the same motifs that were painted later, it may be concluded that the copperplate engravings created subsequently (one of them being the icon of Kykkos Monastery) had their earlier version. This assumed earlier version was known to the icon-painting workshops on the Balkans and in Palestine in the first half of the $19^{\text {th }}$ century, however, such original copperplate engraving has not been discovered yet. Its original model could be the northernmost icon from the iconostas of the Kykkos Monastery. The iconographic theme of this Icon is identical to the one on the the Jerusalem proskynetaria, Bulgarian icons and Greek copperplate engravings, with only a few different details. Based on its stylistic features, it has been ascribed to the icon painter Ioannis Kornaros and dated in 1792. In the same year, he painted another icon for this iconostas, Apostle Luke paints the Icon of Holy Mother, as confirmed by the inscription on this one. This brings us to the conclusion that the scene on the Jerusalem proskynetarion from 1819 in Ružica Church is most probably the result of spreading of appropriate prototype kept in the Kykkos Monas. tery using the unknown copperplate engraving, preserved in the versions created in the mid- $19^{\text {th }}$ century.

\section{Illustrations}

Fig. 1 Jerusalem from Ružica Church in Kalemegdan (photo of the Institute for the Protection of Cultural Monuments of Serbia, Belgrade)

Fig. 2 Inscription of Hajji Petar from 1819 in cartouche, on the back of the icon (photo of the Institute for the Protection of Cultural Monuments of Serbia, Belgrade)

Fig. 3 Apostle Luke presents to the Holy Mother the Icon he painted (photo of the Institute for the Protection of Cultural Monuments of Serbia, Belgrade)

Fig. 4 Apostle Luke presents to the Holy Mother the Icon he painted, lithography, 1848, Convent "Protecting Veil of the Mother of God”, Samokov, Bulgaria (Джурова 2002, with no numeration)

Fig. 5 Apostle Luke presents to the Holy Mother the Icon he painted, copper engraving, 1852, collection of D. Papastratou, Athens, Greece (Papastratou 1990, 587)

Fig. 6 Apostle Luke presents to the Holy Mother the Icon he painted, Icon attributed to Ioannis Kornaros, 1792, iconostas of the Monastery Church Kykkos, Cyprus (Chrysostomos 1969, 38) 